\title{
25-hydroxyvitamin D3 Concentration in Serum and Cerebrospinal Fluid of Patients with Remitting-relapse Multiple Sclerosis
}

\author{
Moghtaderi A. ${ }^{1}$, Tamadon G. H. ${ }^{2}$, Haghighi F. ${ }^{1}$ \\ 1Department of Neurology, Zahedan University of Medical Sciences, Zahedan, Iran; \\ 2Department of Laboratory Medicine, Shiraz University of Medical Sciences, \\ Shiraz, Iran \\ Received December 30, 2012; Accepted August 14, 2013.
}

Key words: Multiple sclerosis - CSF - Vitamin D - Plasma

\begin{abstract}
There is epidemiological, geographical and immunological evidence suggesting that low environmental supplies of vitamin D3 may act as a risk factor for developing multiple sclerosis (MS), possibly due to dysfunction in the immunomodulatory properties of 25-hydroxyvitamin D3 (25-OH-D3) in the brain. The objective of this study is to measure the serum and cerebrospinal fluid (CSF) concentrations of 25-OH-D3 in MS patients during their relapsing phase. 52 patients with remitting-relapse and 58 patients with other non-inflammatory diseases of central and peripheral nervous system were entered into the study. Patients in both groups were admitted for the first time to do diagnostic procedures and they were not on any other treatment for neurological disorders. The means and medians for serum levels of $25-\mathrm{OH}-\mathrm{D} 3$ in MS patients and control group were $10.64 \pm 9.2 \mathrm{ng} / \mathrm{ml}$ (median: $9.6 \mathrm{ng} / \mathrm{ml}$ ) and $13.23 \pm 17.56 \mathrm{ng} / \mathrm{ml}$ (median: $11.90 \mathrm{ng} / \mathrm{ml})$, respectively $(p=0.328)$. CSF concentrations for the same values were $2.02 \pm 1.94 \mathrm{ng} / \mathrm{ml}$ (median: $0.23 \mathrm{ng} / \mathrm{ml}$ ) and $3.28 \pm 2.96$ (median: $0.29 \mathrm{ng} / \mathrm{ml}$ ), respectively $(p=0.242)$. The differences between calculated numbers of serum/CSF ratios were not statistically significant too. The serum and CSF concentrations of 25-OH-D3 in MS group were lower than the control counterpart without any statistical difference and the authors did not find any influence of serum 25-OH-D3 concentration on the CSF concentration based on the non-significant statistical difference between the serum/CSF ratios in two study groups of MS patients and control cases.
\end{abstract}

Mailing Address: Assoc. Prof. Ali Moghtaderi, MD., Department of Neurology, Imam-Ali Teaching Hospital, Zahedan University of Medical Sciences, Zahedan, Iran; Phone: 009854132180 16; Fax: 009854132188 48; e-mails: amoghtaderi@gmail .com, moghtaderi@zaums.ac.ir 


\section{Introduction}

There are epidemiological, geographical and immunological evidences suggesting that the low environmental supplies of vitamin D3 may act as a risk factor for developing multiple sclerosis (MS), possibly due to the immunoregulatory and immunomodulatory functions of 25-hydroxyvitamin D3 (25-OH-D3) in the brain (Holmøy et al., 2009). Vitamin D is now recognized for its benefits in reducing risk of chronic diseases including autoimmune diseases, common cancer and cardiovascular diseases (Holick, 2009). There are some studies confirming that low levels of 25-OH-D3 concentration are associated with an increased risk of MS and higher concentrations, sunlight exposure and vitamin $\mathrm{D}$ consumption may reduce the risk of MS (Lysandropoulos et al., 2011). Intrathecal 25-OH-D3 may play an important role to modulate the neuroprotective effects and neurotransmitter biosynthesis in cerebral tissue (Garcion et al., 2002). Those consist of regulation of nerve growth factor (NGF) (Wion et al., 1991), neurotrophin 3 (NT3) (Neveu et al., 1994) and glial cell line-derived neurotrophic factors (GDNF) (Naveilhan et al., 1996) syntheses. The neuroprotective effect of $25-\mathrm{OH}-\mathrm{D} 3$ may mediate by inhibiting the synthesis of inducible nitric oxide synthase (iNOS), an enzyme induced in neuronal and non-neuronal cells during many inflammatory processes such as infections, MS and experimental autoimmune encephalomyelitis (EAE) (Garcion et al., 2002). Finally, production of high concentration of nitric oxide which is the end product of enzyme activity, will damage both neurons and oligodendrocytes (Garcion et al., 1997, 1998).

The protective effect of 25-OH-D3 has been known since long time ago. The mechanism is by inhibiting CD4 antigen expression and iNOS synthesis within cerebral tissue, however, it was not defined clearly that intrathecal cerebrospinal fluid (CSF) concentration of 25-OH-D3 is correlated with evolving MS (Holmøy et al., 2009) or vitamin D binding proteins in the CNS (Qin et al., 2009) is the responsible factor and acts as a biological marker in the CSF of patients with MS.

The objective of this study was to measure the serum and CSF concentrations of 25-OH-D3 in MS patients during their relapsing phase and compare them with a control group of non-inflammatory neurological disorders in a local Iranian population.

\section{Methods}

Patient selection

The study has been conducted in Sistan and Balouchestan province which is the largest province of Iran near bordering the western side of Pakistan. It is located in south-eastern Iran with a population of more than 2.5 million and a high proportion (45.7\%) of young adults between $16-50$ years. Actually this province is in the subtropical/tropical area with dry and hot weather in summer and dry-cold weather in winter with a high level of ultraviolet ray exposure. Regarding the high costs of different drugs especially interferons for the treatment of MS, all cases 
referred to our university hospital for confirmation of diagnosis at first, therefore misdiagnosis is rare.

The diagnosis was based on clinical findings, brain and spinal cord magnetic resonance imaging (MRI) studies, CSF analyses and visual evoked potential (VEP) according to McDonald criteria and its revision (McDonald et al., 2001; Polman et al., 2005). The authors tested all patients for collagen-vascular diseases and requested antinuclear antibody (ANA), ds-DNA and anti-phospholipid antibody laboratory tests. Routine laboratory examinations, visual evoked potential, CSF analyses, brain, and cervical cord MRI were done in almost all patients. Some of them did not give us consent for performing lumbar puncture; therefore CSF analyses were not done in those patients. Chest X-ray was taken for all patients but the authors did not perform any diagnostic test for sarcoidosis. In order to have an alpha error of $5 \%$ and power of $80 \%$ for detecting clinically significant difference the total calculated number of needed cases was 110 cases in two groups. Totally 52 cases with clinical definite MS were entered into the study. Lumbar puncture was performed in the L4-L5 or L5-S1 intervertebral lumbar spaces. All patients were admitted for the first time and did not treat with immunomodulatory drugs. Lumbar puncture was performed before beginning of treatment, between 8-10 o'clock a.m. Demographic information obtained from patients and/or their relatives included their name, parents' name, age, marital status, education. We had also collected other important clinical data such as the first neurological episode compatible with MS disease (type, month and year), CSF and MRI findings, occupation, and place of residence and/or birth. Serum and CSF samples were stored in refrigerator at $-70{ }^{\circ} \mathrm{C}$ for the later analysis. Control group consists of 58 patients with non-inflammatory CNS diseases such as Alzheimer disease, vascular subcortical dementia, heredo-degenerative peripheral neuropathies, pseudotumor cerebri, intractable epilepsy, and carcinomatous meningitis. The study was approved by the Institutional Ethics Committee of the Zahedan University of Medical Sciences. Written informed consent obtained from all patients prior to enrolment into the study.

\section{Laboratory examination}

For measuring serum and CSF concentration of 25-OH-D3 we used appropriate ELISA kit (Euroimmun, Medizinische Labordiagnostica AG, Germany) and the assays were run according to manufacturer's direction. The assay was also validated and appropriate for a medium such as CSF. After preparation and stabilization of reagents and samples, spectrophotometric measurement of the color intensity has been read by the absorbance at a wavelength of $450 \mathrm{~nm}$ with a reference wave length between $620 \mathrm{~nm}$ and $650 \mathrm{~nm}$ within 30 minutes after adding the stop solution. Test performance was done using fully automated analysis device (Hyperion $^{\mathrm{TM}}$, MicroReader, MRP4 ${ }^{+}$). 


\section{Statistical analysis}

The authors made a standardized report sheet in which data collected stepby-step as described earlier. After an evaluation of the assumption of normal distribution we calculated median, arithmetic mean, and standard deviation values for different variables. Then the authors carried out chi-squared and unpaired two samples $t$-tests comparing age, sex, serum and CSF concentration of 25-OH-D3 between two groups. Pearson's correlation coefficient $(r)$ was used as a measure of association between serum and CSF 25-OH-D3 concentration in each group. Median values were compared by Mann-Whitney $U$ and Wilcoxon rank sum tests, using SPSS software for Windows, version 17 (SPSS Inc., Chicago, IL, USA). Comparisons were labelled as statistically significant at the conventional p-value of less than 0.05 .

\section{Results}

We studied a total of 110 patients in which 52 cases were patients with multiple sclerosis admitted to the hospital for diagnosis confirmation during their relapse phase. The other 58 cases were patients with other non-inflammatory CNS disorders or peripheral neuropathies enrolled in the study as the control group. Thirty-five patients (67.3\%) in MS group and 28 patients (48.2\%) in control group were females. Chi-squared analysis between two groups did not reach to any significant statistical difference. The means of age were $30.2 \pm 10.7$ years

\section{Table 1 - Comparing demographic characteristics, mean and median values for serum and CSF concentrations of vitamin $D$ in two study groups}

\begin{tabular}{|c|c|c|c|}
\hline & $\begin{array}{c}\text { MS group* } \\
\text { (Cl 95\% for means) } \\
\text { [median] }\end{array}$ & $\begin{array}{c}\text { Control group* } \\
\text { (Cl 95\% for means) } \\
\text { [median] }\end{array}$ & P-value \\
\hline $\operatorname{Sex}(F / M)$ & $35 / 17$ & $28 / 30$ & 0.054 \\
\hline Age (years) & $\begin{array}{c}30.2 \pm 10.7 \\
\text { (Cl } 95 \%: 27.2-33.2)\end{array}$ & $\begin{array}{c}35.4 \pm 17.0 \\
\text { (Cl } 95 \%: 30.9-39.9)\end{array}$ & 0.057 \\
\hline $\begin{array}{l}\text { 25-OH-D3 concentration } \\
\text { in CSF }(\mathrm{ng} / \mathrm{ml})\end{array}$ & $\begin{array}{c}2.02 \pm 1.94 \\
(\mathrm{Cl} 95 \%: 0.92-3.12) \\
{[0.23(0.10-16.20)]}\end{array}$ & $\begin{array}{c}3.28 \pm 2.96 \\
(\mathrm{Cl} 95 \%: 1.45-5.11) \\
{[0.29(0.15-41.50)]}\end{array}$ & $\begin{array}{l}0.242 \\
0.554\end{array}$ \\
\hline $\begin{array}{l}25-\mathrm{OH}-\mathrm{D} 3 \text { concentration } \\
\text { in serum }(\mathrm{ng} / \mathrm{ml})\end{array}$ & $\begin{array}{c}10.64 \pm 9.2 \\
(\mathrm{Cl} 95 \%: 8.06-13.21) \\
{[9.60(0.17-36.1)]}\end{array}$ & $\begin{array}{c}13.23 \pm 17.56 \\
(\mathrm{Cl} 95 \%: 8.61-17.85) \\
{[11.90(0.21-120)]}\end{array}$ & $\begin{array}{l}0.328 \\
0.840\end{array}$ \\
\hline Serum/CSF $25-\mathrm{OH}-\mathrm{D} 3$ ratio & $\begin{array}{c}75.51 \pm 94.45 \\
(\mathrm{Cl} 95 \%: 49.13-101.89) \\
{[57.55]}\end{array}$ & $\begin{array}{c}77.65 \pm 100.62 \\
(\mathrm{Cl} 95 \%: 51.22-104.14) \\
{[53.66]}\end{array}$ & $\begin{array}{l}0.304 \\
0.524\end{array}$ \\
\hline
\end{tabular}

*values are for the means \pm standard deviations; MS - multiple sclerosis; CSF - cerebrospinal fluid 
(range: $19-66$ years) and $35.4 \pm 17.0$ years (range: $23-76$ years) in MS and control groups respectively (Table 1 ). The means and medians for measured values of 25-OH-D3 in serum, CSF and their ratio were presented in Table 1. We did not find any statistically significant difference between none of them. Figure 1 shows steam-and-leaf plots for the measured mean values of two groups according to the retrieved data in Table 1. Pearson's correlation coefficients $(r)$ between serum and CSF measured concentrations of 25-OH-D3 in each group were $-0.101 \quad(p=0.474)$ and $0.610(p=0.001)$ for MS cases and control patients respectively. The means for paired difference of two groups of cases and controls were $8.66 \pm 10.34 \mathrm{ng} / \mathrm{ml}$ (Cl 95\%: 5.75-11.56) and $9.47 \pm 15.71 \mathrm{ng} / \mathrm{ml}(\mathrm{Cl} 95 \%: 5.33-13.60)$ respectively without any statistical difference $(p=0.520)$.

\section{Discussion}

The main findings in this study are: (I) The serum and CSF concentrations of $25-\mathrm{OH}-\mathrm{D} 3$ in MS group are less than the control counterpart but statistical analyses did not reveal any significant difference; and (II) we did not find any influence of serum 25-OH-D3 concentration on the CSF concentration based on the non-significant statistical difference between the serum/CSF ratios in two study groups of MS patients and control cases.

Currently there are many observational studies which confirm the role of $25-\mathrm{OH}-\mathrm{D} 3$ as an environmental risk factor for MS. 25-OH-D3 is the best known as a calcium homeostasis modulator, its association with plasma 25-OH-D3 levels (Kampman and Steffensen, 2010), the geographic distribution of MS prevalence (Kurtzke, 2000), the seasonal variation of the disease (Embry et al., 2000), season of birth (Sotgiu et al., 2006), clinical remission of the disease during pregnancy (Sotgiu et al., 2006), the low bone mass density found in MS patients (Ozgocmen et al., 2005), 25-OH-D3 receptor polymorphism (Tajouri et al., 2005) and recently its immunomodulatory role by inhibiting CD4 antigen expression in central nervous system has been shown (Smolders et al., 2008). Both clinical and environmental observations provide evidence for its protective effect which has been supported by reduced risk of MS in associated with sunlight exposure and use of vitamin D supplements in different consuming foods (Correale et al., 2009). It has been reported that intake of vitamin $D$ from supplements was also inversely associated with risk of MS. The relative risk comparing women with intake of $400 \mathrm{IU} /$ day with women with no supplemental vitamin $D$ intake was 0.59 (Cl 95\%: 0.38-0.91; $\mathrm{p}=0.006$ ) (Munger et al., 2004). In another study conducted among American patients showed decreased risk of MS in white individuals with increasing serum concentration of 25-OH-D3. The odds ratio for individuals with 25-OH-D3 serum levels higher than $99.1 \mathrm{nmol} / \mathrm{l}$, was statistically significant $(O R=0.38 ; \mathrm{Cl} 95 \%: 0.19-0.75 ; p=0.006)$. The inverse relation with MS risk was particularly strong for $25-\mathrm{OH}-\mathrm{D} 3$ levels measured before age 20 years (Munger et al., 2006). 
In MS, antigens from the CNS are drained into the peripheral lymphatic system and then they are processed by antigen-presenting cells. The dendritic cells play an important role by priming CD4+, CD8+ T-cell and B-cell responses (Tumani et al., 2009). Current evidence supports the idea in which 1,25-(OH)2-D3 mediates a shift of CD4+ T-cells to an anti-inflammatory profile (Smolders et al., 2008).
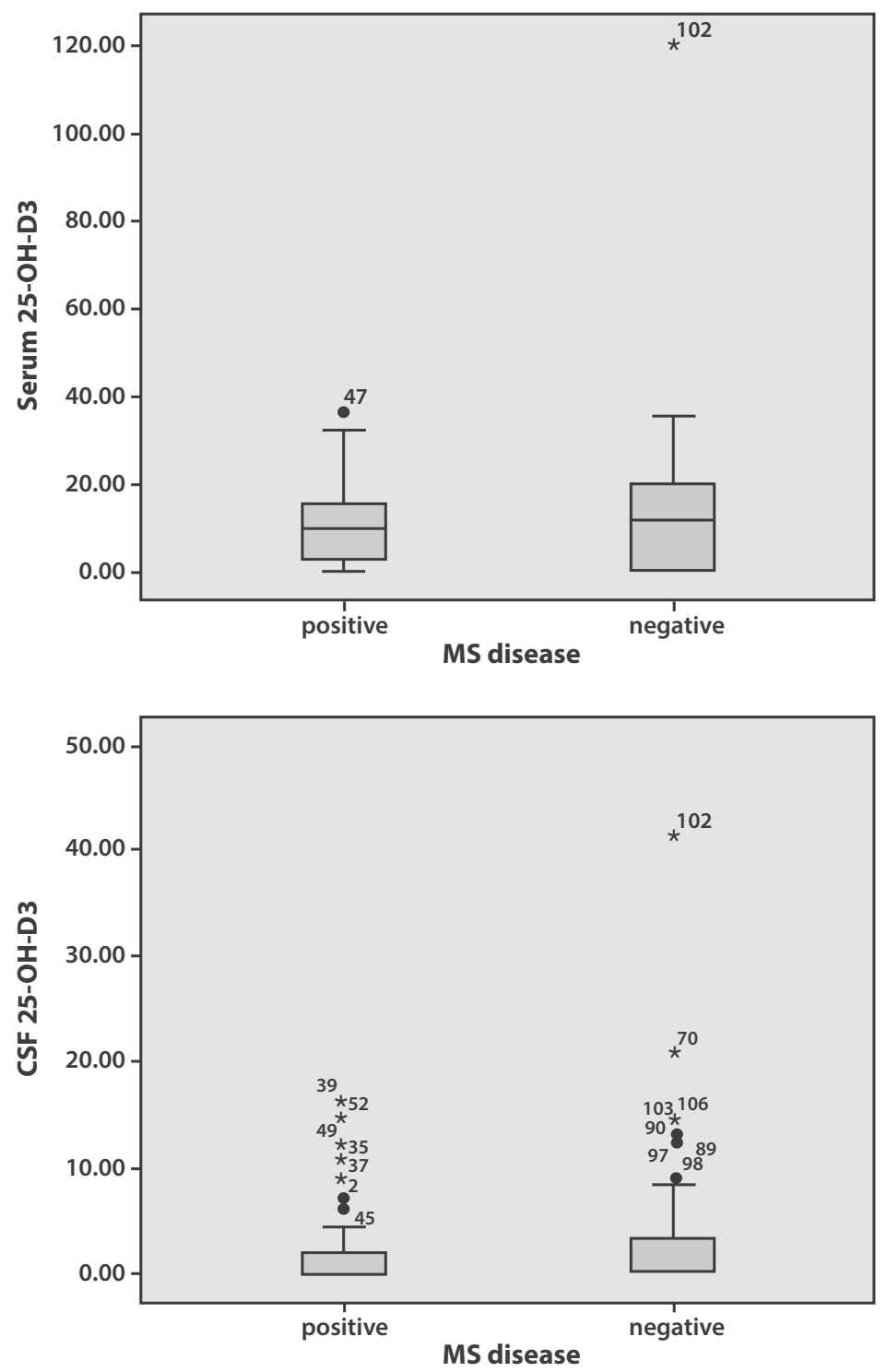

Figure 1 - Box and whisker diagrams of serum and CSF concentrations of 25-OH-D3 in two study groups. 
Moreover, B-cell differentiation, plasma cell and immunoglobulin production are inhibited simultaneously and finally, it plays an important role in the maintenance of B-cell homeostasis (Chen et al., 2007). The majority of the biomarkers of the drained CSF are blood derived (80\%) and the remainder $20 \%$ are intrathecally produced proteins. Based on the physiological rules, they usually enter the CSF compartment via passive diffusion across the blood-CSF barrier which depends on their molecular size, weight and their blood concentration (Felgenhauer, 1974). It is mandatory for CSF biomarker studies to assess CSF and serum samples simultaneously, and they have to use detection systems focused on the examination of the CSF to discriminate whether the biomarker of interest originated from blood circulation or synthesized intrathecally (Giovannoni, 2006). However, in the current study we did not find any correlation between serum and CSF concentration of 25-OH-D3.

Vitamin D metabolites are normal components of the human internal environment. Balabanova et al. (1984) reported CSF concentration of 25-OH-D3 and compared it with their serum concentration in 46 adult patients who were admitted for surgical treatment of lumbar disc herniation without any endocrine dysfunction. The reported results for the medians of 25-OH-D3 were $8.3 \mathrm{ng} / \mathrm{ml}$ (range: $2.0-24.8$ ) in CSF and $14.5 \mathrm{ng} / \mathrm{ml}$ (range: 7.0-36.0) in plasma. They also had not found any correlation between CSF and plasma concentrations probably due to small number of patients or age-related changes in their report.

Normal plasma concentration of 25-OH-D3 in individuals without any endocrine problem is 15-80 ng/ml with a mean of $52 \mathrm{ng} / \mathrm{ml}$ (Pierrot-Deseilligny, 2009). However, most experts agree that plasma concentration of less than $20 \mathrm{ng} / \mathrm{ml}$ of 25-OH-D3 of is considered to be vitamin D deficiency whereas concentrations between 21-29 ng/ml are considered to be insufficient (Holick, 2009). In both groups of MS patients and control group of non-inflammatory CNS disease plasma concentration 25-OH-D3 is too low. However, the authors did not find any difference between them. The finding of higher plasma than CSF concentrations of 25-OH-D3 are as the same finding as Holmøy and his colleague (Holmøy and Kampman, 2010). It should be emphasized that there are numerous confounders such as age, gender, season for sample collection on plasma and CSF concentrations of 25-OH-D3. However, in this study both group had different neurological diseases which may have a positive correlation with $25-\mathrm{OH}-\mathrm{D} 3$ concentration. Meanwhile the mean and median plasma concentrations of 25-OH-D3 had not a significant correlation in control group; the authors did not found such relationship in MS patients. There is a controversy in the potential impact of blood-brain barrier on transportation of 25-OH-D3 into the cerebrospinal fluid. It has been shown that at physiological concentrations of plasma proteins, the extraction by brain of $25-\mathrm{OH}-\mathrm{D} 3$ was $5 \%$ or less (Pardridge et al., 1985). Probably, this is one of the main reasons for negative results in most clinical trials in which MS patients were treated with vitamin D3 (Munger and Ascherio, 2011). Another study showed that 
supplementation of high doses of vitamin D3 does not have substantial effects on phenotypic markers of B-cell differentiation in circulating B-cell (Knippenberg et al., 2011). In particular some authors postulated that low levels of 25-OH-D3 during early life may be relevant to several brain diseases such as multiple sclerosis (Eyles et al., 2005). Moreover, the interaction between 25-OH-D3 as a secosteroid (Brown et al., 2003), its binding protein and the receptors in the cerebral tissue may involve in unexpectedly diverse role in increasing the risk of affecting with MS.

$25-\mathrm{OH}-\mathrm{D} 3$ is tightly bound to vitamin D binding protein (DBP). The structure is quite similar to albumin super-family with more than 120 different species (Gomme and Bertolini, 2004). It was shown in animal studies that the role of DBP was not very crucial for development but was required to mediate inflammatory and immunoregulatory activities in response to environmental challenges (Gomme and Bertolini, 2004). Proteomics analysis showed that the most significant differential protein was DBP, which was decreased in the CSF of MS patients. Their result was confirmed by ELISA method ( $p<0.01$ ) (Qin et al., 2009). The prominent decreased expression of DBP in the CSF of MS patients is probably in correlation with decreased 25-OH-D3 in the CSF. Therefore, the authors suppose that the role of CSF vitamin $\mathrm{D}$ metabolites may be associated with vitamin $\mathrm{D}$ binding proteins in cerebral tissue.

Acknowledgements: This paper was based on MD dissertation of Dr. Farzaneh Haghighi approved and funded by the Dean for Research Affairs at the Zahedan University of Medical Sciences (ZAUMS).

\section{References}

Balabanova, S., Richter, H. P., Antoniadis, G., Homoki, J., Kremmer, N., Hanle, J., Teller, W. M. (1984) 25-hydroxyvitamin D, 24, 25-dihydroxyvitamin D and 1,25-dihydroxyvitamin D in human cerebrospinal fluid. Klin. Wochenschr. 62(22), 1086-1090.

Brown, J., Bianco, J. I., McGrath, J. J., Eyles, D. W. (2003) 1,25-dihydroxyvitamin D3 induces nerve growth factor, promotes neurite outgrowth and inhibits mitosis in embryonic rat hippocampal neurons. Neurosci. Lett. 343(2), 139-143.

Chen, S., Sims, G. P., Chen, X. X., Gu, Y. Y., Chen, S., Lipsky, P. E. (2007) Modulatory effects of 1,25-dihydroxyvitamin D3 on human B cell differentiation. J. Immunol. 179(3), 1634-1647.

Correale, J., Ysrraelit, M. C., Gaitán, M. I. (2009) Immunomodulatory effects of vitamin D in multiple sclerosis. Brain 132(Pt 5), 1146-1160.

Embry, A. F., Snowdon, L. R., Vieth, R. (2000) Vitamin D and seasonal fluctuations of gadolinium-enhancing magnetic resonance imaging lesions in multiple sclerosis. Ann. Neurol. 48(2), 271-272.

Eyles, D. W., Smith, S., Kinobe, R., Hewison, M., McGrath, J. J. (2005) Distribution of the vitamin D receptor and 1 alpha-hydroxylase in human brain. J. Chem. Neuroanat. 29(1), 21-30.

Felgenhauer, K. (1974) Evaluation of molecular size by gel electrophoretic techniques. Hoppe Seylers Z. Physiol. Chem. 355(10), 1281-1290.

Garcion, E., Nataf, S., Berod, A., Darcy, F., Brachet, P. (1997) 1,25-dihydroxyvitamin D3 inhibits the expression of inducible nitric oxide synthase in rat central nervous system during experimental allergic encephalomyelitis. Brain Res. Mol. Brain Res. 45(2), 255-267. 
Garcion, E., Sindji, L., Montero-Menei, C., Andre, C., Brachet, P., Darcy, F. (1998) Expression of inducible nitric oxide synthase during rat brain inflammation: regulation by 1,25-dihydroxyvitamin D3. Glia 22(3), 282-294.

Garcion, E., Wion-Barbot, N., Montero-Menei, C. N., Berger, F., Wion, D. (2002) New clues about vitamin D functions in the nervous system. Trends Endocrinol. Metab. 13(3), 100-105.

Giovannoni, G. (2006) Multiple sclerosis cerebrospinal fluid biomarkers. Dis. Markers 22(4), 187-196.

Gomme, P. T., Bertolini, J. (2004) Therapeutic potential of vitamin D-binding protein. Trends Biotechnol. 22(7), 340-345.

Holick, M. F. (2009) Vitamin D status: measurement, interpretation, and clinical application. Ann. Epidemiol. 19(2), 73-78.

Holmøy, T., Kampman, M. T. (2010) Alaska, multiple sclerosis, and the vitamin D hypothesis. J. Neurol. 257(2), 305-306.

Holmøy, T., Moen, S. M., Gundersen, T. A., Holick, M. F., Fainardi, E., Castellazzi, M., Casetta, I. (2009) 25-hydroxyvitamin D in cerebrospinal fluid during relapse and remission of multiple sclerosis. Mult. Scler. 15(11), 1280-1285.

Kampman, M. T., Steffensen, L. H. (2010). The role of vitamin D in multiple sclerosis. J. Photochem. Photobiol. B 101(2), 137-141.

Knippenberg, S., Smolders, J., Thewissen, M., Peelen, E., Tervaert, J. W., Hupperts, R., Damoiseaux, J. (2011) Effect of vitamin $\mathrm{D}(3)$ supplementation on peripheral B cell differentiation and isotype switching in patients with multiple sclerosis. Mult. Scler. 17(12), 1418-1423.

Kurtzke, J. F. (2000) Multiple sclerosis in time and space - geographic clues to cause. J. Neurovirol. 6, S134-S140 (Suppl. 2).

Lysandropoulos, A. P., Jaquiéry, E., Jilek, S., Pantaleo, G., Schluep, M., Du Pasquier, R. A. (2011) Vitamin D has a direct immunomodulatory effect on CD8+ T cells of patients with early multiple sclerosis and healthy control subjects. J. Neuroimmunol. 233(1-2), 240-244.

McDonald, W. I., Compston, A., Edan, G., Goodkin, D., Hartung, H. P., Lublin, F. D., McFarland, H. F., Paty, D. W., Polman, C. H., Reingold, S. C., Sandberg-Wollheim, M., Sibley, W., Thompson, A., van den Noort, S., Weinshenker, B. Y., Wolinsky, J. S. (2001) Recommended diagnostic criteria for multiple sclerosis: guidelines from the International Panel on the diagnosis of multiple sclerosis. Ann. Neurol. 50(1), 121-127.

Munger, K. L., Ascherio, A. (2011) Prevention and treatment of MS: studying the effects of vitamin D. Mult. Scler. 17(12), 1405-1411.

Munger, K. L., Zhang, S. M., O’Reilly, E., Hernán, M. A., Olek, M. J., Willett, W. C., Ascherio, A. (2004) Vitamin D intake and incidence of multiple sclerosis. Neurology 62(1), 60-65.

Munger, K. L., Levin, L. I., Hollis, B. W., Howard, N. S., Ascherio, A. (2006) Serum 25-hydroxyvitamin D levels and risk of multiple sclerosis. JAMA 296(23), 2832-2838.

Naveilhan, P., Neveu, I., Wion, D., Brachet, P. (1996) 1,25-dihydroxyvitamin D3, an inducer of glial cell linederived neurotrophic factor. Neuroreport 7(13), 2171-2175.

Neveu, I., Naveilhan, P., Baudet, C., Brachet, P., Metsis, M. (1994) 1,25-dihydroxyvitamin D3 regulates NT-3, NT-4 but not BDNF mRNA in astrocytes. Neuroreport 6(1), 124-126.

Ozgocmen, S., Bulut, S., Ilhan, N., Gulkesen, A., Ardicoglu, O., Ozkan, Y. (2005) Vitamin D deficiency and reduced bone mineral density in multiple sclerosis: effect of ambulatory status and functional capacity. J. Bone Miner. Metab. 23(4), 309-313.

Pardridge, W. M., Sakiyama, R., Coty, W. A. (1985) Restricted transport of vitamin D and A derivatives through the rat blood-brain barrier. J. Neurochem. 44(4), 1138-1141.

Pierrot-Deseilligny, C. (2009) Clinical implications of a possible role of vitamin D in multiple sclerosis. J. Neurol. 256(9), 1468-1479. 
Polman, C. H., Reingold, S. C., Edan, G., Filippi, M., Hartung, H. P., Kappos, L., Lublin, F. D., Metz, L. M., McFarland, H. F., O’Connor, P. W., Sandberg-Wollheim, M., Thompson, A. J., Weinshenker, B. G., Wolinsky, J. S. (2005)

Diagnostic criteria for multiple sclerosis: 2005 revisions to the "McDonald Criteria". Ann. Neurol. 58(6), 840-846.

Qin, Z., Qin, Y., Liu, S. (2009) Alteration of DBP levels in CSF of patients with MS by proteomics analysis. Cell. Mol. Neurobiol. 29(2), 203-210.

Smolders, J., Damoiseaux, J., Menheere, P., Hupperts, R. (2008) Vitamin D as an immune modulator in multiple sclerosis, a review. J. Neuroimmunol. 194(1-2), 7-17.

Sotgiu, S., Pugliatti, M., Sotgiu, M. A., Fois, M. L., Arru, G., Sanna, A., Rosati, G. (2006) Seasonal fluctuation of multiple sclerosis births in Sardinia.J. Neurol. 253(1), 38-44.

Tajouri, L., Ovcaric, M., Curtain, R., Johnson, M. P., Griffiths, L. R., Csurhes, P., Pender, M. P., Lea, R. A. (2005) Variation in the vitamin D receptor gene is associated with multiple sclerosis in an Australian population. J. Neurogenet. 19(1), 25-38.

Tumani, H., Hartung, H. P., Hemmer, B., Teunissen, C., Deisenhammer, F., Giovannoni, G., Zettl, U. K.; BioMS Study Group (2009) Cerebrospinal fluid biomarkers in multiple sclerosis. Neurobiol. Dis. 35(2), 117-127.

Wion, D., MacGrogan, D., Neveu, I., Jehan, F., Houlgatte, R., Brachet, P. (1991) 1,25-dihydroxyvitamin D3 is a potent inducer of nerve growth factor synthesis. J. Neurosci. Res. 28(1), 110-114. 